\title{
Rho, ROCK and actomyosin contractility in metastasis as drug
}

\section{targets [version 1; peer review: 2 approved]}

\section{Irene Rodriguez-Hernandez ${ }^{1 *}$, Gaia Cantelli ${ }^{1 *}$, Fanshawe Bruce ${ }^{1,2}$, Victoria Sanz-Moreno ${ }^{1}$}

\footnotetext{
${ }^{1}$ Tumour Plasticity Laboratory, Randall Division of Cell and Molecular Biophysics, Guy's Campus, King's College London, London, SE1 1 UL, UK

${ }^{2}$ Department of Imaging Chemistry and Biology, Division of Imaging Sciences and Biomedical Engineering, St. Thomas Hospital, King's College London, London, SE1 7EH, UK

* Equal contributors
}

V1 First published: 29 Apr 2016, 5(F1000 Faculty Rev):783

https://doi.org/10.12688/f1000research.7909.1

Latest published: 29 Apr 2016, 5(F1000 Faculty Rev):783

https://doi.org/10.12688/f1000research.7909.1

\section{Abstract}

Metastasis is the spread of cancer cells around the body and the cause of the majority of cancer deaths. Metastasis is a very complex process in which cancer cells need to dramatically modify their cytoskeleton and cope with different environments to successfully colonize a secondary organ. In this review, we discuss recent findings pointing at Rho-ROCK or actomyosin force (or both) as major drivers of many of the steps required for metastatic success. We propose that these are important drug targets that need to be considered in the clinic to palliate metastatic disease.

Keywords

Rho-ROCK, actomyosin, metastasis, Rho

\section{Open Peer Review \\ Approval Status \\ 1 \\ 2 \\ version 1 \\ 29 Apr 2016 \\ Faculty Reviews are review articles written by the prestigious Members of Faculty Opinions. The articles are commissioned and peer reviewed before publication to ensure that the final, published version is comprehensive and accessible. The reviewers who approved the final version are listed with their names and affiliations.}

1. Martin A. Schwartz, Yale University School of Medicine, New Haven, USA

2. Michael Olson, Cancer Research UK Beatson Institute, Glasgow, UK

Any comments on the article can be found at the end of the article. 
Corresponding author: Victoria Sanz-Moreno (victoria.sanz_moreno@kcl.ac.uk)

Competing interests: The authors declare that they have no competing interests.

Grant information: This work was supported by Cancer Research UK C33043/A12065 (Victoria Sanz-Moreno and Irene RodriguezHernandez) and Royal Society RG110591 (Victoria Sanz-Moreno). Irene Rodriguez-Hernandez is supported by Fundacion Alfonso Martin Escudero, Gaia Cantelli by the Medical Research Council (C97993H), and Bruce Fanshawe by the King's Bioscience Institute and the Guy's and St Thomas' Charity Prize PhD Program in Biomedical and Translational Science.

The funders had no role in study design, data collection and analysis, decision to publish, or preparation of the manuscript.

Copyright: ๑ 2016 Rodriguez-Hernandez I et al. This is an open access article distributed under the terms of the Creative Commons Attribution License, which permits unrestricted use, distribution, and reproduction in any medium, provided the original work is properly cited.

How to cite this article: Rodriguez-Hernandez I, Cantelli G, Bruce F and Sanz-Moreno V. Rho, ROCK and actomyosin contractility in metastasis as drug targets [version 1; peer review: 2 approved] F1000Research 2016, 5(F1000 Faculty Rev):783

https://doi.org/10.12688/f1000research.7909.1

First published: 29 Apr 2016, 5(F1000 Faculty Rev):783 https://doi.org/10.12688/f1000research.7909.1 


\section{Introduction}

Metastatic disease is still largely incurable because of its systemic distribution and resistance to current therapies, and it is the cause of more than $90 \%$ of cancer-related deaths ${ }^{1,2}$. In spite of its clinical importance, the underlying cellular and molecular mechanisms of cancer metastasis are only partially understood ${ }^{3}$. Thus, improved knowledge of how cancer cells acquire metastatic traits is necessary to unravel novel drug targets and prognostic markers of distant relapse.

Metastasis is a complex multi-stage process by which cancer cells disseminate from primary tumors, survive in distant sites and eventually grow as secondary tumors ${ }^{3}$. The main events of the metastatic cascade involve loss of cell-cell contacts, cancer cell migration, local invasion of the surrounding extracellular matrix (ECM), interactions with stroma, intravasation and transit into blood or lymphatic vessels, arrest at secondary sites, extravasation, survival and colonization of distant sites ${ }^{4}$. Genetic alterations and deregulation of critical oncogenic signaling pathways affecting survival, proliferation, apoptosis, and cell motility, regulate many of these complex metastatic events ${ }^{3,5}$. In addition, the interaction with the tumor microenvironment such as ECM, growth-supportive stromal cells, inflammatory cells and endothelial cells strongly impacts the metastatic capabilities of cancer cells ${ }^{6,7}$.

Many signaling pathways have been reported to have an impact on metastasis and have been the focus of excellent reviews ${ }^{8-15}$. In the present review, we will focus on Rho-ROCK signaling and actomyosin contractility, key regulators of several main steps in metastasis. Rho-ROCK, through its actions on cytoskeletal dynamics and through regulation of critical signaling pathways, controls several cellular processes important for metastasis such as cell migration, local invasion, survival at the secondary site, and tumor outgrowth $^{16-18}$.

\section{Rho GTPases and metastasis}

The Rho family of small GTPases plays crucial roles in the regulation of the actin cytoskeleton, cell polarity, cell migration, cell proliferation, invasion, and metastasis ${ }^{19}$. Rho GTPases act as molecular switches cycling between a guanosine triphosphate (GTP)-bound active state and guanosine diphosphate (GDP)-bound inactive state to translate extracellular signals into different cellular responses ${ }^{19}$. Their activity is controlled by guanine nucleotide exchange factors (GEFs) and GTPase-activating proteins (GAPs) ${ }^{18}$. The best studied and most conserved Rho family members across eukaryotic species are Ras-related C3 botulinum toxin substrate 1 (Rac1), cell division control protein 42 homolog (Cdc42), and Ras homolog gene family member A (RhoA $)^{18}$. Rac1 stimulates lamellipodia formation ${ }^{20}$, whereas RhoA regulates the formation of stress fibers or favors amoeboid migration depending on the cellular context and the properties of the matrix. RhoA bound to GTP leads to activation of its effectors Rho-associated protein kinases (ROCK1 and ROCK2) ${ }^{21-23}$. ROCK1/2 serine/ threonine kinases promote actomyosin contractile force generation by decreasing myosin phosphatase activity and thereby increasing phosphorylation of myosin light chain 2 (MLC2) ${ }^{24}$. On the other hand, Cdc42 induces filopodia formation ${ }^{25}$, but $\mathrm{Cdc} 42$ signaling can also generate actomyosin contraction through p21 protein (Cdc42/Rac)-activated kinase 2 (PAK2) and myotonic dystrophy kinase-related Cdc42-binding kinase (MRCK) kinases ${ }^{26,27}$. Deregulation of the Rho-ROCK signaling pathway has been found in a variety of cancer types and in several cases correlates with disease progression ${ }^{28-30}$ (Table 1). Furthermore, inhibition of ROCK signaling could suppress migration and invasion in vitro and impair

Table 1. Rho, ROCK or actomyosin contractility are implicated in all stages of the metastatic cascade and in major cancer types. Shown are examples in the literature of where different stages of the metastatic cascade have been shown to be influenced by Rho-ROCK and/or actomyosin contractility signalling. (SCC = Squamous cell carcinoma)

\begin{tabular}{|c|c|c|}
\hline Cancer type & Step of metastatic dissemination & Reference \\
\hline Breast, colon & Local invasion and migration & $40,46,52,68$ \\
\hline Breast & Intravasation & $40,66,71$ \\
\hline Breast & $\begin{array}{l}\text { Survival in circulation, adhesion to } \\
\text { vessels, early lung colonization }\end{array}$ & 92 \\
\hline Oesophageal & Invasion and survival in circulation & 104 \\
\hline Lung & Transendothelial migration & 81 \\
\hline Prostate & Transendothelial migration & 75 \\
\hline SCC & $\begin{array}{l}\text { Fibroblast mediated invasion and } \\
\text { migration }\end{array}$ & 42 \\
\hline Melanoma & Local invasion and migration & $23,32,45,46,49,105$ \\
\hline Melanoma & $\begin{array}{l}\text { Intravasation, extravasation, survival in } \\
\text { circulation, adhesion to vessels, early } \\
\text { lung colonization }\end{array}$ & $23,32,48,54,58,92,95-97,105$ \\
\hline
\end{tabular}


the metastatic process in vivo, suggesting that ROCK inhibitors might be potential anti-metastatic agents $\mathrm{s}^{30-32}$.

\section{Rho/ROCK signaling and actomyosin contractility in early dissemination}

The ability of cancer cells to migrate into and invade surrounding tissue is a critical step in the metastatic cascade, which requires increased cell motility driven by altered cytoskeletal organization and contacts with the ECM and the stroma ${ }^{33}$. Cancer cells can move either collectively or as individual cells ${ }^{34,35}$. The majority of tumors originate from epithelial tissues, and epithelial cancer cells that leave the primary tumor undergo a complex program called epithelial-mesenchymal transition (EMT). Incomplete or partial EMT allows collective migration in which cells can maintain cell-cell adhesions and migrate collectively in a coordinated manner as strands, sheets, or cell clusters. On the other hand, complete EMT is associated with the loss of cell-cell adhesions in favor of cell-ECM interactions and the concomitant acquisition of individual migratory characteristics ${ }^{36,37}$. After undergoing EMT, individual cancer cells can engage into elongated mesenchymal or rounded amoeboid modes of movement, distinguished by their different usage of signaling pathways. Mixed mesenchymal and amoeboid phenotypes have also been identified ${ }^{38,39}$. Individual cell migration seems to be required for blood-borne metastasis ${ }^{40}$.

\section{Rho/ROCK signaling and actomyosin contractility in cancer} cells

Actomyosin contractility driven by Rho or ROCK signaling is key in controlling tumor dissemination, as all forms of cell migration require a certain degree of actomyosin force ${ }^{34,41}$. During collective cell migration, actomyosin contractility is high around the edges of groups of invading cancer cells, which generates pulling forces between the substrate and the follower cells, together with a prominent actomyosin ring at lateral regions of the groups to maintain coupling between cells and collective forward movement ${ }^{42,43}$. On the other hand, in individual migration, the contractile cortex is crucially important for amoeboid to intermediate forms of movement, and some degree of contractility is also required to retract protrusions in mesenchymal migration $^{39,44-46}$. The mesenchymal mode of movement is characterized by an elongated, spindle-like shape, high levels of adhesion, and Rac-dependent adhesive actin-rich protrusions ${ }^{23,46,47}$. On the other side of the spectrum, in amoeboid migration, cancer cells adopt a rounded or irregular morphology with blebs as functional protrusions. Amoeboid motility is promoted by high levels of RhoA/Ras homolog gene family member C (RhoC) or ROCKdriven actomyosin contractility and requires lower levels of adhesion that allow higher speeds of movement ${ }^{46-50}$.

Cancer cell migration is a dynamic process, and individual cancer cells can switch between modes of movement to adapt to the changing microenvironment and facilitate tumor dissemination. Different cues will favor either a mesenchymal-amoeboid transition (MAT) or an amoeboid-mesenchymal transition (AMT) ${ }^{23,45,49,51,52}$. Their core regulatory network is the mutually inhibitory circuit between Rac1 and Rho GTPase signaling in migrating cells (Figure 1). Higher Rac1 activity promotes cell elongation and permits long actin-rich protrusions characteristic of mesenchymal migration.
Moreover, active Rac1 negatively regulates Rho or ROCK signaling and suppresses amoeboid movement. On the other hand, active Rho or ROCK supports bleb-based amoeboid migration ${ }^{23,45,49,51,52}$ and limits excessive Rac1-dependent adhesion via regulation of the Rac GAPs ARHGAP22 and filamin-A-associated Rho GTPase activation protein (FilGAP) ${ }^{23,53}$. Furthermore, cancer cells control amoeboid migration at the transcriptional level under circumstances in which matrix compliance allows sustained actomyosin contractility (Figure 1). Different chemical cues have been shown to control this process. For instance, amoeboid melanoma cells support contractility, establishing a positive feedback loop with the cytokines leukemia inhibitory factor (LIF)/IL6 and the Janus kinase (JAK)/signal transducer and activator of transcription (STAT) pathway to maintain Rho-ROCK activity ${ }^{49}$. As a result of high STAT3 activity, very contractile cells secrete different factors, including matrix metalloprotease 9 (MMP-9). MMP-9 promotes the generation of actomyosin contractile force and bleb-driven migration through a positive feedback loop via CD44 binding and increased MLC2 phosphorylation to sustain amoeboid invasion ${ }^{48}$. Moreover, amoeboid contractile cells secrete high levels of transforming growth factor beta (TGF $\beta$ ), and downstream of it a Sma- and Mad-related protein 2 (SMAD2)-Cbp/P300-interacting transactivator with Glu/Asp-rich carboxy-terminal domain (CITED1) transcriptional network sustains actomyosin contractility ${ }^{54}$. In addition, the physical properties of the matrix play an important role in establishing a balance between actomyosin levels and adhesion to regulate optimal migration efficiency ${ }^{34,39,47,55,56}$. Increased ECM density results in increased matrix stiffness, in which cells sense and respond by increasing Rho-mediated actomyosin contractility ${ }^{57}$. Furthermore, slow mesenchymal cells can switch to fast amoeboid migrating modes under conditions of low adhesiveness and high physical confinement ${ }^{47,56}$.

The ability to switch between different modes of migration is an important factor for metastatic dissemination, as cancer cells have to migrate through a range of ECMs to escape the primary tumor and spread to distant organs. Therefore, anti-metastatic treatments should target the ability of tumor cells to cope with such variability. Recently, it has been described that potent ROCK inhibitors are able to strongly inhibit actomyosin contractility and collapse the actomyosin cytoskeleton, blocking both mesenchymal and amoeboid modes of movement ${ }^{32}$.

Intra-vital imaging studies have shown that bleb-driven highly contractile amoeboid migration is favored in the invasive fronts of melanomas and breast cancers ${ }^{23,29,45,48,49,58}$. Furthermore, in these studies, it has been shown that treatment with ROCK inhibitors or actomyosin perturbations (or both) is able to decrease tumor cell motility in vivo $o^{23,29,32,45,49,58}$. Hence, ROCK inhibition could effectively impair local invasion and dissemination of cancer cells (Figure 1).

\section{Rho/ROCK signaling and actomyosin contractility in the stroma}

Within the tumor, a variety of non-cancer stromal cells interact with the cancer cells promoting tumorigenesis ${ }^{7}$. Actomyosin contractility not only is fundamental for cancer cell migration and invasion but also is crucial for maintenance of the carcinoma-associated 


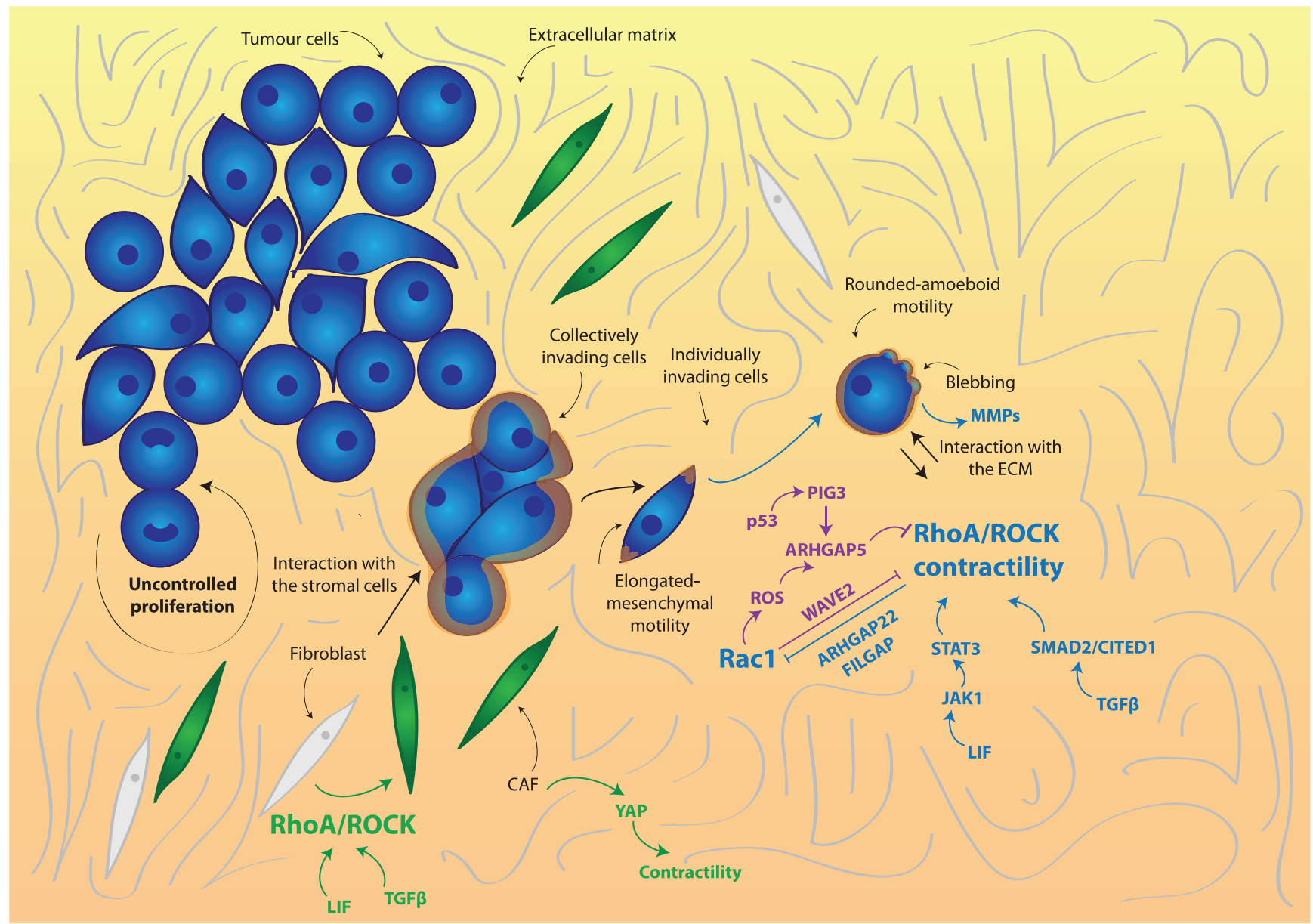

Figure 1. Rho/ROCK and actomyosin contractility in early dissemination. ROCK-driven actomyosin contractility is stimulated by extracellular signals such as leukemia inhibitory factor (LIF) and transforming growth factor beta (TGF $\beta$ ) to promote rounded amoeboid cancer cell motility. Rounded amoeboid cells display blebbing as well as high levels of actomyosin contractility and a rounded morphology. They interact with the extracellular matrix (ECM) by physically deforming it and by secreting metalloproteases (MMPs). In the stroma, ROCK-driven actomyosin contractility promotes the transformation of fibroblasts into cancer-associated fibroblasts (CAFs), driven by Yes-associated protein (YAP) as well as by extracellular factors. Blue indicates positive regulators of contractility, purple indicates negative regulators of contractility and orange lines indicate actomyosin contractility. Abbreviations: CAF, carcinoma-associated fibroblasts; CITED1, Cbp/P300-interacting transactivator with Glu/Asp-rich carboxy-terminal domain, 1; FilGAP, filamin-A-associated Rho GTPase activation protein; JAK, Janus kinase; RhoA, Ras homolog gene family member A; ROCK, Rho-associated protein kinase; SMAD2, Sma- and Mad-related protein 2; STAT3, signal transducer and activator of transcription 3.

fibroblasts (CAFs) phenotype, an important stromal component in the tumor microenvironment ${ }^{7}$. Actomyosin contractility activated by ROCK signaling and the LIF/JAK/STAT pathway is crucial for CAF-dependent pro-invasive physical remodeling of the ECM favoring tumor aggressiveness and dissemination ${ }^{42,49,59,60}$. Additionally, actomyosin contractility, Src function, and matrix stiffening induced by TGF $\beta$, are required for Yes-associated protein (YAP) activation in CAFs to promote ECM remodeling and cancer cell invasion, and to generate a positive feedback loop that helps to maintain the CAF phenotype ${ }^{61}$ (Figure 1). Moreover, contractility in CAFs has been shown to modulate EMT and metastasisinitiating cell properties in breast cancer models ${ }^{62}$.

Therefore, some degree of actomyosin contractility is essential for both cancer cells and stroma for efficient cell movement in the initial steps of the metastatic cascade ${ }^{34,41,49,59,61}$, and some factors such as TGF $\beta$ and LIF can stimulate contractility both in cancer cells and in fibroblasts.

\section{Rho/ROCK signaling and actomyosin contractility in transendothelial migration}

After local invasion within the primary tumor microenvironment, cancer cells need to spread throughout the body and colonize new organs to form metastases. They do so by exploiting the vascular and lymphatic systems. The process through which cancer cells enter and exit vessels crossing the endothelial layer is known as transendothelial migration, which is extremely complex and involves the interaction with several different cell types, such as platelets, immune cells and endothelial cells, and the activation of a variety of signaling pathways ${ }^{63}$. These events are in some 
cases similar to those occurring during inflammation or infection, when immune cells need to enter and exit vessels. In fact, parallels between cancer cell and immune cell migration allow for interesting speculation in areas of cancer cell dissemination that are still not fully understood.

Intravasation. The first step in this metastatic cascade is intravasation, the entry of tumor cells into blood vessels. Intravasation depends on the weakening of cell-cell junctions between endothelial cells, which allows cancer cells to squeeze in between adjacent endothelial cells and enter the vessel lumen ${ }^{63}$. From a molecular perspective, not as much is known about intravasation compared with other steps in the metastatic cascade as this is an experimentally challenging step to study ${ }^{64,65}$. In fact, intravasation is dependent on the ability of cancer cells to invade towards blood vessels, so it is difficult to distinguish between genes involved in invasion and intravasation ${ }^{63}$. RhoA signaling has been linked to the process of intravasation ${ }^{66}$ (Figure 2). Specifically, RhoA activity in cancer cells is thought to be stimulated by macrophage contact and leads to the formation of invadopodia. Invadopodia are instrumental in the degradation and eventual breakdown of the matrix barrier, which allows for tumor cell intravasation. Furthermore, highly contractile, rounded amoeboid melanoma cells have been shown to intravasate more efficiently than low-contractility elongated cells in vivo ${ }^{67,68}$. Once in the bloodstream, cells are transported throughout the body by the blood flow (Figure 2).

Extravasation. Eventually, cancer cells flowing through the bloodstream need to exit blood vessels to form secondary tumors. This process is known as extravasation and entails several sequential steps. First of all, cancer cells form loose adhesions to the vascular endothelium, which is known as tethering. These loose adhesions then are tightened to form firm adhesions: firmly adhering cells then can cross the endothelial barrier and extravasate ${ }^{63}$.

The best-studied mechanism for extravasation is known as paracellular extravasation, during which cancer cells exit the vessel by squeezing in between endothelial cells. An alternative mechanism for cancer cell extravasation is transcellular extravasation, where tumor cells exit the vessel by going through endothelial

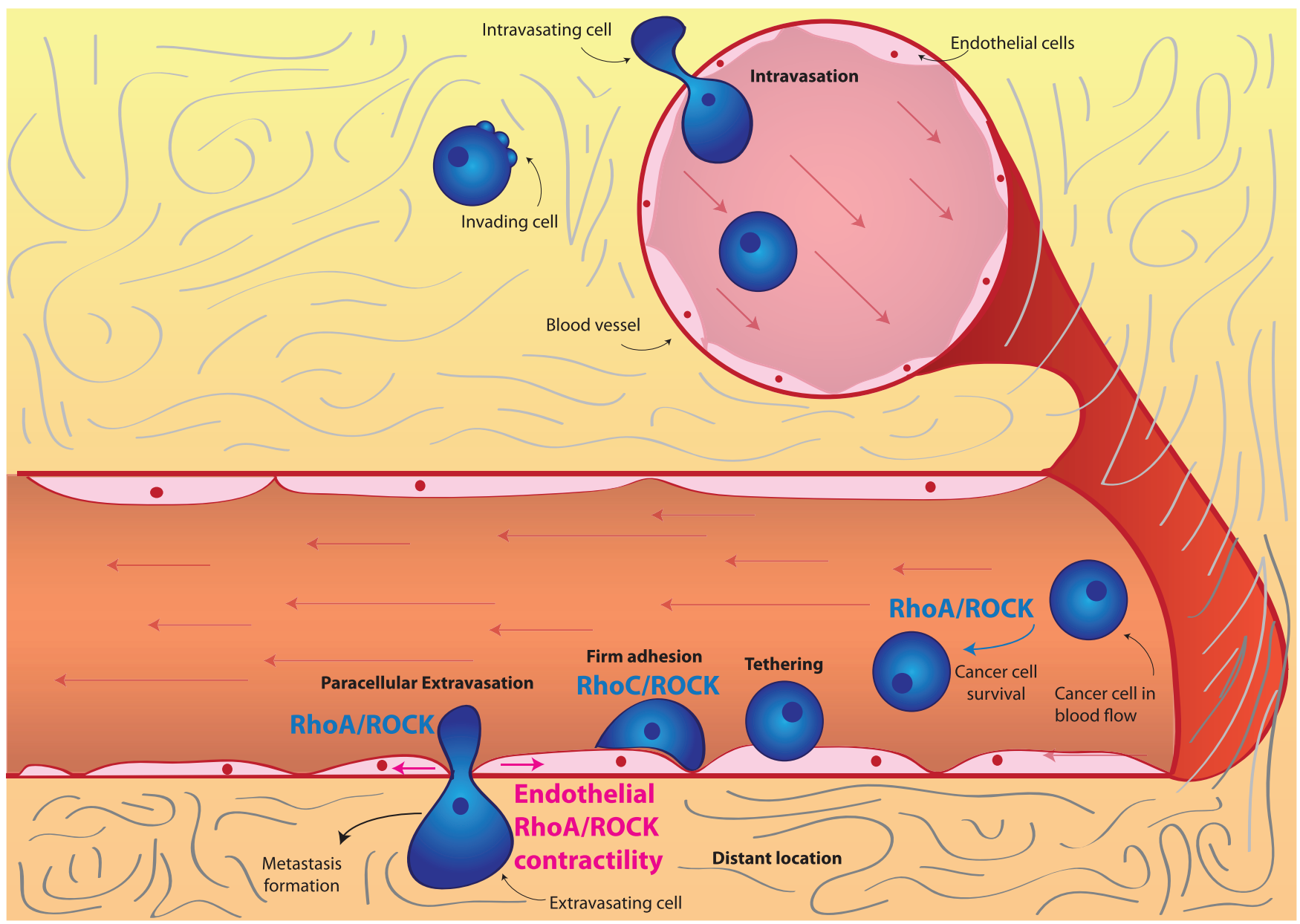

Figure 2. Rho/ROCK and actomyosin contractility in intravasation and extravasation. RhoC/ROCK signaling promotes survival of cancer cells in the blood flow as well as adhesion to the endothelium and extravasation. ROCK-driven actomyosin contractility within endothelial cells can be stimulated by secreted factors and is essential for cancer cell extravasation. Abbreviations: RhoC, Ras homolog gene family member C; ROCK, Rho-associated protein kinase. 
cells $^{63,69}$. Transcellular extravasation has been observed in immune cells ${ }^{70}$ and has also been identified in cancer cells, where it probably plays a role in some cases ${ }^{71}$.

\section{Rho/ROCK signaling and actomyosin contractility in cancer cells}

Rho or ROCK-driven actomyosin contractility within extravasating cells has been shown to play an important role. For instance, in monocytes, RhoA activity has been shown to be necessary for tail retraction during extravasation ${ }^{72}$. In the context of transcellular extravasation, monocytes can rely on RhoA and ROCK signaling ${ }^{73,74}$.

On the other hand, in prostate cancer cells, it is RhoC and ROCK signaling that is essential for interaction with endothelial cells, promoting adhesion and paracellular extravasation ${ }^{75}$. As a result of its role in promoting extravasation, RhoC signaling is a key driver of tumor dissemination and metastasis ${ }^{75}$, in part explaining how $R h o C$ was one of the first genes identified as a metastasis driver ${ }^{76}$. Furthermore, RhoA and RhoC have been shown to drive adhesion to the endothelium and transendothelial migration in breast and prostate cancer cells $\mathrm{s}^{77,78}$. Consequently, rounded-amoeboid cancer cells with high levels of RhoA or ROCK-driven actomyosin contractility are more efficient during transendothelial migration than elongated cells both in vitro and in vivo ${ }^{67,68,79}$. Additional evidence supporting the importance of RhoA-driven contractility in transendothelial migration comes from studies examining the role of RhoA regulators. For instance, FilGAP, a Rac GAP, promotes RhoA signaling and rounded-amoeboid motility by suppressing Rac, and as a consequence it enhances in vivo extravasation of breast cancer cells ${ }^{53}$. Conversely, the RhoA GAP ARHGAP7 has been shown to be a negative regulator of transendothelial migration in thymic lymphoma ${ }^{80}$.

Cancer cells that successfully extravasate need to cross the vascular basement membrane that surrounds the vessel ${ }^{63}$. Since actomyosin contractility has been shown to promote the secretion of proteases in rounded amoeboid cells ${ }^{48}$, it is tempting to speculate that highly contractile extravasating cells could have an advantage when crossing the vascular basement membrane.

\section{Rho/ROCK signaling and actomyosin contractility in endothelial cells}

In order for paracellular extravasation to occur, cancer cells need to weaken cell-cell junctions within the endothelium. This can be mediated by regulating Rho or ROCK signaling and actomyosin contractility within the endothelial cells themselves (Figure 2). Lung cancer cells have been shown to induce adherens junction disassembly by stimulating actomyosin contractility through Rho/ROCK in endothelial cells ${ }^{81}$. Furthermore, thrombin stimulation of endothelial cells has been shown to induce ROCK activity and subsequently lead to cytoskeletal remodeling, junction disruption, and endothelial permeability ${ }^{82,83}$. Tumor-derived thrombin induces endothelial gap formation and transendothelial migration ${ }^{84}$. Furthermore, cancer cells have been shown to use thrombin within blood vessels in order to promote metastasis ${ }^{85}$. This prompts the speculation that actomyosin contraction in endothelial cells could be controlled by thrombin produced by cancer cells.
As well as leading to junction disassembly, actomyosin contractility in endothelial cells allows for endothelial cell retraction ${ }^{86,87}$, which increases endothelial permeability. Moreover, ROCK-driven actomyosin contractility in endothelial cells has been shown to prevent endothelial cell re-spreading downstream of ephrin-B signaling, which maintains increased endothelial permeability ${ }^{88}$. Conversely, ROCK inhibition has been shown to decrease endothelial permeability after hemorrhage ${ }^{89,90}$. Although these studies have not been conducted in cancer models, ROCK activity in endothelial cells could be similarly regulated while in contact with disseminating cancer cells.

In brief, we speculate that the ability of cancer cells to form secondary tumors is to a certain extent dependent on their ability to manipulate the cytoskeleton of endothelial cells; thus, increasing endothelial permeability could be a crucial step to promote extravasation. More work is needed to validate the roles of Rho/ROCK or actomyosin contractility (or both) in tumor cells during both cancer intravasation and extravasation.

\section{Rho/ROCK signaling and actomyosin contractility in metastatic colonization}

Following extravasation at secondary sites, cancer cells that survive can form micro-metastasis and colonize new sites. In order for this colonization to take place, cancer cells must be able to adhere to endothelial cells, extravasate, survive and proliferate at the secondary site. The first few hours of colonization are crucial in determining the success of this process, as cells will undergo apoptosis if they do not adhere to their new niche. Furthermore, once established, cells must be able to evade the immune response in order to survive ${ }^{91}$. Although we have discussed that Rho/ROCK signaling is important for early dissemination, there is also evidence to suggest that Rho/ROCK signaling, actomyosin contractility or its regulators, or a combination of these are important for efficient colonization at secondary sites.

In vivo studies where cancer cells are injected intravenously (i.e., experimental metastasis assays) show that high levels of actomyosin contractility play a role in seeding of and colonizing the lung. For instance, cells selected for efficient colonization in the lung such as the highly metastatic A375M2 melanoma cell line have higher levels of RhoC ${ }^{76}$, RhoA ${ }^{23}$ and phosphorylated MLC2 ${ }^{48}$ when compared with low metastatic A375P melanoma cells.

Several studies have confirmed the importance of the initial hours in seeding during colonization. For example, serum response factor (SRF) co-activators myocardin-related transcription factors (MRTFs) are able to control the expression of $\mathrm{MLC2}^{92}$ (Figure 3). MRTF and SRF are both important for early stages of lung colonization in breast cancer and melanoma ${ }^{92}$. Furthermore, depletion of MLC2 itself has also been shown to reduce lung colonization $^{92}$. Conversely, enhanced actomyosin contractility favors colonization: for example, depletion of the actomyosin contractility suppressors Rac1 and its GEF dedicator of cytokinesis 3 (DOCK3) favors early lung colonization ${ }^{23}$. In melanoma, pigment epithelium-derived factor (PEDF) reduces lung colonization and suppresses lung tumor outgrowth ${ }^{93,94}$. PEDF is a negative regulator of Rho-ROCK signaling through supporting DOCK3-Rac1 activity $^{95}$ (Figure 3). Furthermore, oncogenic BRAF suppresses 


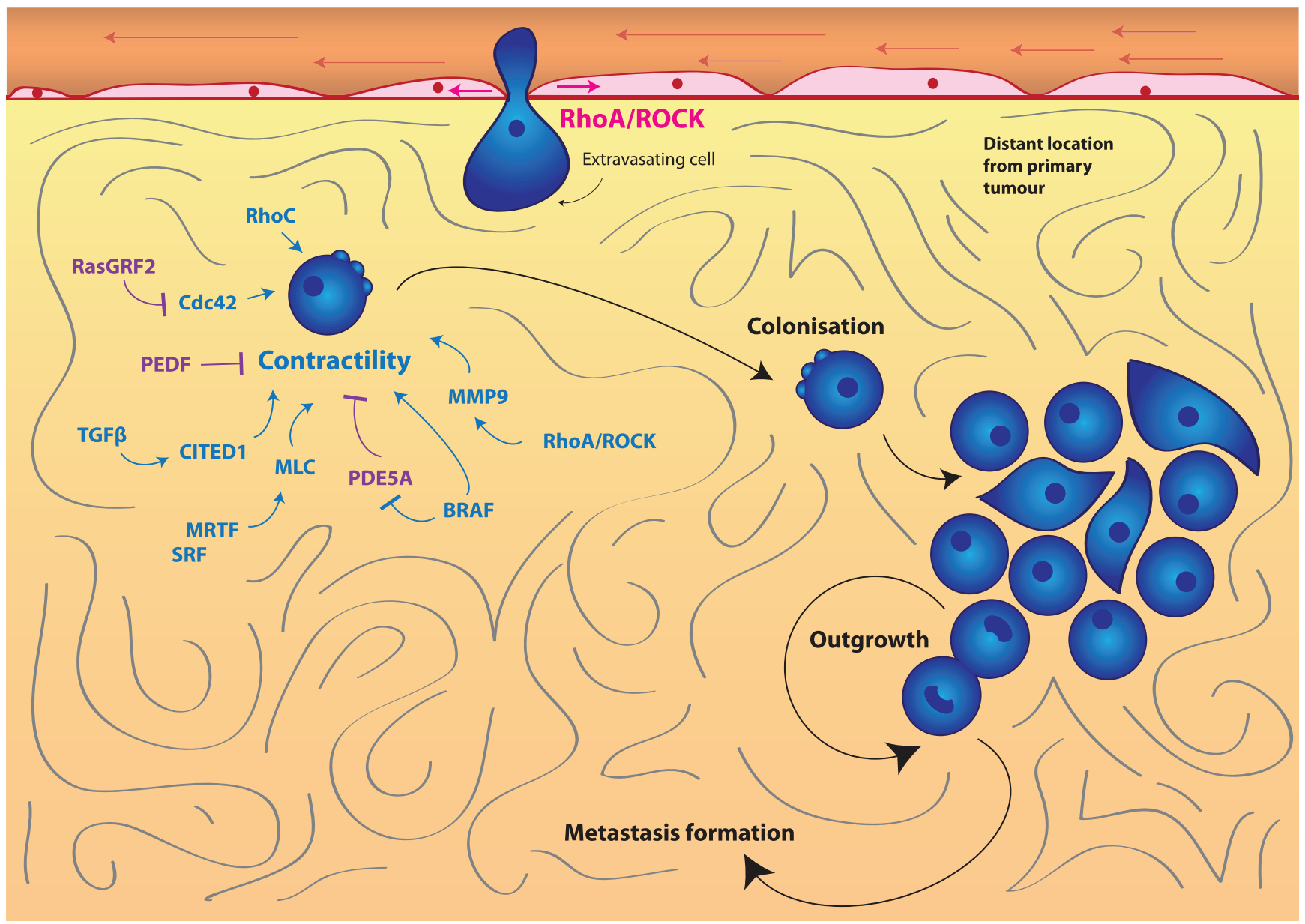

Figure 3. Rho/ROCK and actomyosin contractility in colonization and metastasis. Actomyosin contractility promotes cancer cel colonization and outgrowth at a secondary site to form metastases. Contractility is under the control of a wide variety of pathways, including SRF/MRTF, TGF $\beta-S M A D-C I T E D 1$, MMP-9, BRAF-V600E and Cdc42 signaling. Blue indicates positive regulators of contractility, and purple indicates negative regulators of contractility. Abbreviations: CITED1, Cbp/P300-interacting transactivator with Glu/Asp-rich carboxy-terminal domain, 1; Cdc42, cell division control protein 42 homolog; MLC2, myosin light chain 2; MMP, matrix metallopeptidase; MRTF, myocardin-related transcription factors; PDE5A, phosphodiesterase 5A; PEDF, pigment epithelium-derived factor; RasGRF2, Ras protein-specific guanine nucleotide-releasing factor 2; ROCK, Rho-associated protein kinase; SMAD, Sma- and Mad-related protein; SRF, serum response factor; TGF $\beta$, transforming growth factor beta.

phosphodiesterase 5A (PDE5A), which in turn inhibits actomyosin contractility ${ }^{96}$ (Figure 3). Therefore, re-expression of PDE5A reduces the ability of melanoma cells to colonize the lung and prevents short-term survival and long-term cancer growth in the lung ${ }^{96}$.

As mentioned earlier, Cdc42 can also promote actomyosin contractility in cancer cells ${ }^{26}$. Further evidence of the importance of actomyosin contractility in early colonization has been shown by experiments in which loss of Ras protein-specific guanine nucleotide-releasing factor 2 (RasGRF2), an inhibitor of $\mathrm{Cdc}^{2} 2^{97}$, enhanced colonization of the lungs in a Rac-independent manner. This was associated with higher actomyosin contractility levels ${ }^{97}$ (Figure 3).

TGF $\beta$ signaling plays an important role in promoting cancer cell colonization ${ }^{40,54,98}$ (Figure 3 ). We recently found that TGF $\beta$ increases actomyosin contractility in melanoma cells ${ }^{54}$. While TGF $\beta$ is known to promote $\mathrm{EMT}^{99}$ in epithelial cancers, in melanoma TGF $\beta$ signals through SMAD2 and the adaptor CITED1 to support contractile amoeboid migration ${ }^{54}$. TGF $\beta$ no longer sustains lung colonization in melanoma cells if the SMAD2-CITED1 axis is not functional ${ }^{54}$, which serves to highlight the multiple levels in which actomyosin contractility promotes colonization.

Furthermore, ROCK regulates expression of several MMPs, including MMP-9, which promote early stages of lung colonization ${ }^{48}$ (Figure 3). While MMPs exert their catalytic function in degradation of the ECM during local invasion, the non-catalytic roles of MMP-9 could promote the survival of cancer cells at the metastatic secondary sites. For example, it has been shown that non-catalytic functions of MMP-9 regulate STAT3 functions to drive survival in B-cell chronic lymphocytic leukemia (B-CLL) cells ${ }^{100}$. 
From these results, it is clear that positive and negative regulators of Rho/ROCK signaling or actomyosin contractility (or both) are critical for cancer cells to efficiently colonize the metastatic sites in experimental metastasis models.

We have highlighted the crucial role that Rho/ROCK signaling or actomyosin contractility play in dissemination and metastatic colonization using a range of experimental cancer models. A highly contractile phenotype is clearly critical for effective cancer colonization, ultimately supporting the idea of developing drugs to inhibit actomyosin contractility. In vivo validation of the role of Rho/ROCK signaling or actomyosin contractility (or both) in metastasis is important to qualify these signaling modules as potential drug targets. Experimental metastasis models are insightful for understanding the processes of extravasation and colonization to the lungs, but recapitulation of the entire metastatic cascade, including local invasion, dissemination and intravasation, requires the use of spontaneous metastasis models ${ }^{101}$. Indeed, it has recently been shown that a new class of ROCK inhibitors has the ability to prevent both experimental and spontaneous metastases formation ${ }^{32}$. It will be of great importance to combine these mouse models with non-invasive cell-tracking techniques ${ }^{102,103}$ to understand the entire process and how early Rho/ROCK signaling should be targeted in order to effectively block the metastatic cascade.

\section{Abbreviations}

CAF, carcinoma-associated fibroblasts; CITED1, Cbp/P300interacting transactivator with Glu/Asp-rich carboxy-terminal domain, 1; Cdc42, cell division control protein 42 homolog; DOCK3, dedicator of cytokinesis 3; ECM, extracellular matrix;
EMT, epithelial-mesenchymal transition; FilGAP, filamin-Aassociated Rho GTPase activation protein; GEF, guanine nucleotide exchange factor; GAP, GTPase activation protein; GTP, guanosine triphosphate; JAK, Janus kinase; LIF, leukemia inhibitory factor; MLC2, myosin light chain 2; MMP, matrix metallopeptidase; MRTF, myocardin-related transcription factors; PDE5A, phosphodiesterase 5A; PEDF, pigment epitheliumderived factor; Rac1, Ras-related C3 botulinum toxin substrate 1; RasGRF2, Ras protein-specific guanine nucleotide-releasing factor 2; RhoA, Ras homolog gene family member A; RhoC, Ras homolog gene family member C; ROCK, Rho-associated protein kinase; SMAD2, Sma- and Mad-related protein 2; SRF, serum response factor; STAT, signal transducer and activator of transcription; TGF $\beta$, transforming growth factor beta.

\section{Competing interests}

The authors declare that they have no competing interests.

\section{Grant information}

This work was supported by Cancer Research UK C33043/A12065 (Victoria Sanz-Moreno and Irene Rodriguez-Hernandez) and Royal Society RG110591 (Victoria Sanz-Moreno). Irene RodriguezHernandez is supported by Fundacion Alfonso Martin Escudero, Gaia Cantelli by the Medical Research Council (C97993H), and Bruce Fanshawe by the King's Bioscience Institute and the Guy's and St Thomas' Charity Prize PhD Program in Biomedical and Translational Science.

The funders had no role in study design, data collection and analysis, decision to publish, or preparation of the manuscript.
1. Valastyan S, Weinberg RA: Tumor metastasis: molecular insights and evolving paradigms. Cell. 2011; 147(2): 275-92. PubMed Abstract | Publisher Full Text | Free Full Text

2. Gupta GP, Massagué J: Cancer metastasis: building a framework. Cell. 2006 127(4): 679-95.

PubMed Abstract | Publisher Full Text

3. Vanharanta S, Massagué J: Origins of metastatic traits. Cancer Cell. 2013; 24(4): 410-21.

PubMed Abstract | Publisher Full Text | Free Full Text

4. Talmadge JE, Fidler IJ: AACR centennial series: the biology of cancer metastasis: historical perspective. Cancer Res. 2010; 70(14): 5649-69. PubMed Abstract | Publisher Full Text | Free Full Text

5. Kim S: New and emerging factors in tumorigenesis: an overview. Cancer Manag Res. 2015; 7: 225-39.

PubMed Abstract | Publisher Full Text | Free Full Text

6. Psaila B, Lyden D: The metastatic niche: adapting the foreign soil. Nat Rev Cancer. 2009; 9(4): 285-93.

PubMed Abstract | Publisher Full Text | Free Full Text

7. Quail DF, Joyce JA: Microenvironmental regulation of tumor progression and metastasis. Nat Med. 2013; 19(11): 1423-37. PubMed Abstract | Publisher Full Text | Free Full Text

8. Anastas JN, Moon RT: WNT signalling pathways as therapeutic targets in cancer. Nat Rev Cancer. 2013; 13(1): 11-26. PubMed Abstract | Publisher Full Text
9. Padua D, Massagué J: Roles of TGFbeta in metastasis. Cell Res. 2009; 19(1): 89-102.

PubMed Abstract | Publisher Full Text

10. Wakefield LM, Hill CS: Beyond TGF $\beta$ : roles of other TGF $\beta$ superfamily members in cancer. Nat Rev Cancer. 2013; 13(5): 328-41. PubMed Abstract | Publisher Full Text

11. Nguyen DX, Massagué J: Genetic determinants of cancer metastasis. Nat Rev Genet. 2007; 8(5): 341-52.

PubMed Abstract | Publisher Full Text

12. Alizadeh AM, Shiri S, Farsinejad S: Metastasis review: from bench to bedside. Tumour Biol. 2014; 35(9): 8483-523. PubMed Abstract | Publisher Full Text

13. Powell E, Piwnica-Worms D, Piwnica-Worms $\mathrm{H}$ : Contribution of $\mathrm{p} 53$ to metastasis. Cancer Discov. 2014; 4(4): 405-14. PubMed Abstract | Publisher Full Text | Free Full Text

14. Polivka J Jr, Janku F: Molecular targets for cancer therapy in the PI3K/AKT/mTOR pathway. Pharmacol Ther. 2014; 142(2): 164-75. PubMed Abstract | Publisher Full Text

15. Jiang WG, Sanders AJ, Katoh M, et al:: Tissue invasion and metastasis: Molecular, biological and clinical perspectives. Semin Cancer Biol. 2015; 35(Suppl): S244-75. PubMed Abstract | Publisher Full Text

16. Orgaz JL, Herraiz C, Sanz-Moreno V: Rho GTPases modulate malignant transformation of tumor cells. Small GTPases. 2014; 5(4): e29019. PubMed Abstract | Publisher Full Text | Free Full Text 
17. Rath N, Olson MF: Rho-associated kinases in tumorigenesis: re-considering ROCK inhibition for cancer therapy. EMBO Rep. 2012; 13(10): 900-8. PubMed Abstract | Publisher Full Text | Free Full Text

18. Ridley AJ: Rho GTPase signalling in cell migration. Curr Opin Cell Biol. 2015; 36 103-12.

PubMed Abstract | Publisher Full Text | Free Full Text

19. Jaffe AB, Hall A: Rho GTPases: biochemistry and biology. Annu Rev Cell Dev Biol. 2005; 21: 247-69.

PubMed Abstract | Publisher Full Text

20. Ridley AJ, Paterson HF, Johnston CL, et al:: The small GTP-binding protein rac regulates growth factor-induced membrane ruffling. Cell. 1992; 70(3): 401-10. PubMed Abstract | Publisher Full Tex

21. Amano M, Chihara K, Kimura K, et al.: Formation of actin stress fibers and focal adhesions enhanced by Rho-kinase. Science. 1997; 275(5304): 1308-11. PubMed Abstract | Publisher Full Tex

22. Kimura $\mathrm{K}$, Ito $\mathrm{M}$, Amano $\mathrm{M}$, et al:: Regulation of myosin phosphatase by Rho and Rho-associated kinase (Rho-kinase). Science. 1996; 273(5272): 245-8. PubMed Abstract | Publisher Full Text

23. F Sanz-Moreno V, Gadea G, Ahn J, et al.: Rac activation and inactivation control plasticity of tumor cell movement. Cell. 2008; 135(3): 510-23. PubMed Abstract | Publisher Full Text | F1000 Recommendation

24. Ito M, Nakano T, Erdodi F, et al:: Myosin phosphatase: structure, regulation and function. Mol Cell Biochem. 2004; 259(1-2): 197-209. PubMed Abstract | Publisher Full Text

25. Nobes $C D$, Hall A: Rho, rac, and cdc42 GTPases regulate the assembly of multimolecular focal complexes associated with actin stress fibers, lamellipodia, and filopodia. Cell. 1995; 81(1): 53-62.

PubMed Abstract | Publisher Full Text

26. Gadea G, Sanz-Moreno V, Self A, et al:: DOCK10-mediated Cdc42 activation is necessary for amoeboid invasion of melanoma cells. Curr Biol. 2008; 18(19): $1456-65$.

PubMed Abstract | Publisher Full Text

27. Wilkinson S, Paterson HF, Marshall CJ: Cdc42-MRCK and Rho-ROCK signalling cooperate in myosin phosphorylation and cell invasion. Nat Cell Biol. 2005; 7(3): 255-61.

PubMed Abstract | Publisher Full Text

28. Sahai E, Marshall CJ: RHO-GTPases and cancer. Nat Rev Cancer. 2002; 2(2): 33-42.

PubMed Abstract | Publisher Full Tex

29. Herraiz C, Calvo F, Pandya P, et al:: Reactivation of p53 by a Cytoskeletal Sensor to Control the Balance Between DNA Damage and Tumor Dissemination. J Natl Cancer Inst. 2016; 108(1): pii: djv289. PubMed Abstract | Publisher Full Text | Free Full Text

30. F Liu S, Goldstein RH, Scepansky EM, et al: Inhibition of rho-associated kinase signaling prevents breast cancer metastasis to human bone. Cancer Res. 2009; 69(22): 8742-51. PubMed Abstract | Publisher Full Text | F1000 Recommendation

31. $F$ Patel RA, Liu Y, Wang B, et al:: Identification of novel ROCK inhibitors with anti-migratory and anti-invasive activities. Oncogene. 2014; 33(5): 550-5. PubMed Abstract | Publisher Full Text | Free Full Text | F1000 Recommendation

32. F Sadok A, McCarthy A, Caldwell J, et al.: Rho kinase inhibitors block melanoma cell migration and inhibit metastasis. Cancer Res. 2015; 75(11) 2272-84.

PubMed Abstract | Publisher Full Text | F1000 Recommendation

33. F Hanahan D, Weinberg RA: Hallmarks of cancer: the next generation. Cell. 2011; 144(5): 646-74.

PubMed Abstract | Publisher Full Text | F1000 Recommendation

34. Friedl $\mathrm{P}$, Wolf K: Plasticity of cell migration: a multiscale tuning model. $J \mathrm{Ce} / \mathrm{J}$ Biol. 2010; 188(1): 11-9.

PubMed Abstract | Publisher Full Text | Free Full Text

35. F Wolf $\mathrm{K}, \mathrm{Wu} \mathrm{YI}$, Liu $\mathrm{Y}$, et al:: Multi-step pericellular proteolysis controls the transition from individual to collective cancer cell invasion. Nat Cell Biol. 2007; 9(8): 893-904.

PubMed Abstract | Publisher Full Text | F1000 Recommendation

36. Thiery JP, Acloque H, Huang RY, et al.: Epithelial-mesenchymal transitions in development and disease. Cell. 2009; 139(5): 871-90.

PubMed Abstract | Publisher Full Text

37. Tsai JH, Yang J: Epithelial-mesenchymal plasticity in carcinoma metastasis. Genes Dev. 2013; 27(20): 2192-206.

PubMed Abstract | Publisher Full Text | Free Full Text

38. Friedl $\mathrm{P}$, Alexander $\mathrm{S}$ : Cancer invasion and the microenvironment: plasticity and reciprocity. Cell. 2011; 147(5): 992-1009.

PubMed Abstract | Publisher Full Tex

39. F Lämmermann T, Sixt M: Mechanical modes of 'amoeboid' cell migration Curr Opin Cell Biol. 2009; 21(5): 636-44.

PubMed Abstract | Publisher Full Text | F1000 Recommendation

40. F Giampieri S, Manning C, Hooper S, et al:: Localized and reversible TGFbeta signalling switches breast cancer cells from cohesive to single cell motility.
Nat Cell Biol. 2009; 11(11): 1287-96.

PubMed Abstract | Publisher Full Text | Free Full Text | F1000 Recommendation

41. Sanz-Moreno V, Marshall CJ: The plasticity of cytoskeletal dynamics underlying neoplastic cell migration. Curr Opin Cell Biol. 2010; 22(5): 690-6. PubMed Abstract | Publisher Full Text

42. F Gaggioli C, Hooper S, Hidalgo-Carcedo C, et al:: Fibroblast-led collective invasion of carcinoma cells with differing roles for RhoGTPases in leading and following cells. Nat Cell Biol. 2007; 9(12): 1392-400.

PubMed Abstract | Publisher Full Text | F1000 Recommendation

43. Friedl $\mathrm{P}$, Wolf $\mathrm{K}$, Zegers MM: Rho-directed forces in collective migration. Nat Cell Biol. 2014; 16(3): 208-10.

PubMed Abstract | Publisher Full Tex

44. F Charras GT, Hu CK, Coughlin M, et al:: Reassembly of contractile actin cortex in cell blebs. J Cell Biol. 2006; 175(3): 477-90.

PubMed Abstract | Publisher Full Text | Free Full Text | F1000 Recommendation

45. F Tozluoğlu M, Tournier AL, Jenkins RP, et al:: Matrix geometry determines optimal cancer cell migration strategy and modulates response to interventions. Nat Cell Biol. 2013; 15(7): 751-62.

PubMed Abstract | Publisher Full Text | F1000 Recommendation

46. Sahai E, Marshall CJ: Differing modes of tumour cell invasion have distinct requirements for Rho/ROCK signalling and extracellular proteolysis. Nat Cell Biol. 2003; 5(8): 711-9.

PubMed Abstract | Publisher Full Text

47. F Liu YJ, Le Berre M, Lautenschlaeger F, et al:: Confinement and low adhesion induce fast amoeboid migration of slow mesenchymal cells. Cell. 2015; 160(4): $659-72$.

PubMed Abstract | Publisher Full Text | F1000 Recommendation

48. Orgaz JL, Pandya P, Dalmeida R, et al.: Diverse matrix metalloproteinase functions regulate cancer amoeboid migration. Nat Commun. 2014; 5: 4255. PubMed Abstract | Publisher Full Text | Free Full Text

49. F Sanz-Moreno V, Gaggioli C, Yeo M, et al:: ROCK and JAK1 signaling cooperate to control actomyosin contractility in tumor cells and stroma. Cancer Cell. 2011; 20(2): 229-45.

PubMed Abstract | Publisher Full Text | F1000 Recommendation

50. F Lorentzen A, Bamber J, Sadok A, et al.: An ezrin-rich, rigid uropod-like structure directs movement of amoeboid blebbing cells. J Cell Sci. 2011; 124(Pt 8): 1256-67.

PubMed Abstract | Publisher Full Text | F1000 Recommendation

51. Pinner S, Sahai $\mathrm{E}$ : Imaging amoeboid cancer cell motility in vivo. J Microsc. 2008; 231(3): 441-5.

PubMed Abstract | Publisher Full Tex

52. F Wyckoff JB, Pinner SE, Gschmeissner S, et al.: ROCK- and myosin-dependent matrix deformation enables protease-independent tumor-cell invasion in vivo. Curr Biol. 2006; 16(15): 1515-23.

PubMled Abstract | Publisher Full Text | F1000 Recommendation

53. F Saito K, Ozawa Y, Hibino K, et al.: FilGAP, a Rho/Rho-associated protein kinase-regulated GTPase-activating protein for Rac, controls tumor cell migration. Mol Biol Cell. 2012; 23(24): 4739-50.

PubMed Abstract | Publisher Full Text | Free Full Text | F1000 Recommendation

54. Cantelli G, Orgaz JL, Rodriguez-Hernandez I, et al:: TGF- $\beta$-Induced Transcription Sustains Amoeboid Melanoma Migration and Dissemination. Curr Biol. 2015; 25(22): 2899-914.

PubMed Abstract | Publisher Full Text | Free Full Text

55. Doyle AD, Petrie RJ, Kutys ML, et al.: Dimensions in cell migration. Curr Opin Cell Biol. 2013; 25(5): 642-9.

PubMed Abstract | Publisher Full Text | Free Full Text

56. F Ruprecht V, Wieser S, Callan-Jones A, et al:: Cortical contractility triggers a stochastic switch to fast amoeboid cell motility. Cell. 2015; 160(4): 673-85. PubMed Abstract | Publisher Full Text | Free Full Text | F1000 Recommendation

57. Provenzano PP, Keely PJ: Mechanical signaling through the cytoskeleton regulates cell proliferation by coordinated focal adhesion and Rho GTPase signaling. J Cell Sci. 2011; 124(Pt 8): 1195-205. PubMed Abstract | Publisher Full Text | Free Full Text

58. F Pinner S, Sahai E: PDK1 regulates cancer cell motility by antagonising inhibition of ROCK1 by RhoE. Nat Cell Biol. 2008; 10(2): 127-37. PubMed Abstract | Publisher Full Text | F1000 Recommendation

59. F Albrengues J, Bourget I, Pons $\mathrm{C}$, et al.: LIF mediates proinvasive activation of stromal fibroblasts in cancer. Cell Rep. 2014; 7(5): 1664-78. PubMed Abstract | Publisher Full Text | F1000 Recommendation

60. Albrengues J, Bertero $\mathrm{T}$, Grasset $\mathrm{E}$, et al:: Epigenetic switch drives the conversion of fibroblasts into proinvasive cancer-associated fibroblasts. Nat Commun 2015; 6: 10204.

PubMed Abstract | Publisher Full Text | Free Full Text

61. F Calvo F, Ege N, Grande-Garcia A, et al.: Mechanotransduction and YAPdependent matrix remodelling is required for the generation and maintenance of cancer-associated fibroblasts. Nat Cell Biol. 2013; 15(6): 637-46. PubMed Abstract | Publisher Full Text | Free Full Text | F1000 Recommendation 
62. F Del Pozo Martin Y, Park D, Ramachandran A, et al: Mesenchymal Cancer Cell-Stroma Crosstalk Promotes Niche Activation, Epithelial Reversion, and Metastatic Colonization. Cell Rep. 2015; 13(11): 2456-69.

PubMed Abstract | Publisher Full Text | Free Full Text | F1000 Recommendation

63. Reymond N, d'Água BB, Ridley AJ: Crossing the endothelial barrier during metastasis. Nat Rev Cancer. 2013; 13(12): 858-70.

PubMed Abstract | Publisher Full Text

64. Harney AS, Arwert EN, Entenberg D, et al.: Real-Time Imaging Reveals Local, Transient Vascular Permeability, and Tumor Cell Intravasation Stimulated by TIE2 ${ }^{\text {hi }}$ Macrophage-Derived VEGFA. Cancer Discov. 2015; 5(9): 932-43. PubMed Abstract | Publisher Full Text | Free Full Text

65. Patsialou A, Bravo-Cordero JJ, Wang Y, et al: Intravital multiphoton imaging reveals multicellular streaming as a crucial component of in vivo cell migration in human breast tumors. Intravital. 2013; 2(2): e25294. PubMed Abstract | Publisher Full Text | Free Full Text

66. F Roh-Johnson M, Bravo-Cordero JJ, Patsialou A, et al:: Macrophage contact induces RhoA GTPase signaling to trigger tumor cell intravasation. Oncogene. 2014; 33(33): 4203-12.

PubMed Abstract | Publisher Full Text | Free Full Text | F1000 Recommendation

67. Sahai E: Illuminating the metastatic process. Nat Rev Cancer. 2007; 7(10): 737-49.

PubMed Abstract | Publisher Full Text

68. F Sahai E, Garcia-Medina R, Pouysségur J, et al.: Smurf1 regulates tumor cell plasticity and motility through degradation of RhoA leading to localized inhibition of contractility. J Cell Biol. 2007; 176(1): 35-42.

PubMed Abstract | Publisher Full Text | Free Full Text | F1000 Recommendation

69. Tremblay PL, Huot J, Auger FA: Mechanisms by which E-selectin regulates diapedesis of colon cancer cells under flow conditions. Cancer Res. 2008; 68(13): 5167-76.

PubMed Abstract | Publisher Full Text

70. Engelhardt B, Wolburg H: Mini-review: Transendothelial migration of leukocytes: through the front door or around the side of the house? Eur J Immunol. 2004; 34(11): 2955-63.

PubMed Abstract | Publisher Full Text

71. F Khuon S, Liang L, Dettman RW, et al:: Myosin light chain kinase mediates transcellular intravasation of breast cancer cells through the underlying endothelial cells: a three-dimensional FRET study. J Cell Sci. 2010; 123(Pt 3) 431-40.

PubMed Abstract | Publisher Full Text | Free Full Text | F1000 Recommendation

72. F Worthylake RA, Lemoine S, Watson JM, et al:: RhoA is required for monocyte tail retraction during transendothelial migration. J Cell Biol. 2001; 154(1): $147-60$.

PubMed Abstract | Publisher Full Text | Free Full Text | F1000 Recommendation

73. Honing $\mathrm{H}$, van den Berg TK, van der Pol SM, et al:: RhoA activation promotes transendothelial migration of monocytes via ROCK. J Leukoc Biol. 2004; 75(3): 523-8.

PubMed Abstract | Publisher Full Text

74. F Heasman SJ, Carlin LM, Cox S, et al.: Coordinated RhoA signaling at the leading edge and uropod is required for $\mathrm{T}$ cell transendothelial migration. J Cell Biol. 2010; 190(4): 553-63.

PubMed Abstract | Publisher Full Text | Free Full Text | F1000 Recommendation

75. F Reymond N, Im JH, Garg R, et al:: RhoC and ROCKs regulate cancer cell interactions with endothelial cells. Mol Oncol. 2015; 9(6): 1043-55.

PubMed Abstract | Publisher Full Text | Free Full Text | F1000 Recommendation

76. Clark EA, Golub TR, Lander ES, et al:: Genomic analysis of metastasis reveals an essential role for RhoC. Nature. 2000; 406(6795): 532-5. PubMed Abstract | Publisher Full Text

77. F Reymond N, Im JH, Garg R, et al:: Cdc42 promotes transendothelial migration of cancer cells through $\beta 1$ integrin. J Cell Biol. 2012; 199(4): 653-68. PubMed Abstract | Publisher Full Text | Free Full Text | F1000 Recommendation

78. F Yagi $\mathrm{H}$, Tan W, Dillenburg-Pilla $\mathrm{P}$, et al:: A synthetic biology approach reveals a CXCR4- $\mathrm{G}_{13}-$-Rho signaling axis driving transendothelial migration of metastatic breast cancer cells. Sci Signal. 2011; 4(191): ra60. PubMed Abstract | Publisher Full Text | Free Full Text | F1000 Recommendation

79. $F$ Borrull A, Ghislin S, Deshayes F, et al:: Nanog and Oct4 overexpression increases motility and transmigration of melanoma cells. J Cancer Res Clin Oncol. 2012; 138(7): 1145-54.

PubMed Abstract | Publisher Full Text | F1000 Recommendation

80. F Sabbir MG, Prieditis H, Ravinsky E, et al.: The role of Dlc1 isoform 2 in K-Ras2 ${ }^{\mathrm{G} 12 \mathrm{D}}$ induced thymic cancer. PLoS One. 2012; 7(7): e40302. PubMed Abstract | Publisher Full Text | Free Full Text | F1000 Recommendation

81. $\mathrm{F}$ Li B, Zhao WD, Tan ZM, et al:: Involvement of Rho/ROCK signalling in small cell lung cancer migration through human brain microvascular endothelial cells. FEBS Lett. 2006; 580(17): 4252-60.

PubMed Abstract | Publisher Full Text | F1000 Recommendation

82. F Gavard J, Gutkind JS: Protein kinase C-related kinase and ROCK are required for thrombin-induced endothelial cell permeability downstream from Galpha12/13 and Galpha ${ }_{11 / q}$. J Biol Chem. 2008; 283(44): 29888-96. PubMed Abstract | Publisher Full Text | Free Full Text | F1000 Recommendation

83. $\mathrm{F}$ van Nieuw Amerongen GP, van Delft S, Vermeer MA, et al:: Activation of RhoA by thrombin in endothelial hyperpermeability: role of Rho kinase and protein tyrosine kinases. Circ Res. 2000; 87(4): 335-40. PubMed Abstract | Publisher Full Text | F1000 Recommendation

84. F Zhang P, Feng S, Liu G, et al:: Mutant B-Raf(V600E) Promotes Melanoma Paracellular Transmigration by Inducing Thrombin-mediated Endothelial Junction Breakdown. J Biol Chem. 2016; 291(5): 2087-106. PubMed Abstract | Publisher Full Text | Free Full Text | F1000 Recommendation

85. F Nierodzik ML, Karpatkin S: Thrombin induces tumor growth, metastasis, and angiogenesis: Evidence for a thrombin-regulated dormant tumor phenotype. Cancer Cell. 2006; 10(5): 355-62.

PubMed Abstract | Publisher Full Text | F1000 Recommendation

86. Riento K, Ridley AJ: Rocks: multifunctional kinases in cell behaviour. Nat Rev Mol Cell Biol. 2003: 4(6): 446-56.

PubMed Abstract | Publisher Full Tex

87. Wysolmerski RB, Lagunoff $D$ : Involvement of myosin light-chain kinase in endothelial cell retraction. Proc Natl Acad Sci U S A. 1990; 87(1): 16-20. PubMed Abstract | Publisher Full Text | Free Full Text

88. F Groeger G, Nobes CD: Co-operative Cdc42 and Rho signalling mediates ephrinB-triggered endothelial cell retraction. Biochem J. 2007; 404(1): 23-9.

PubMed Abstract | Publisher Full Text | Free Full Text | F1000 Recommendation

89. $F$ Huang $B$, Krafft $P R, M a ~ Q$, et al:: Fibroblast growth factors preserve bloodbrain barrier integrity through RhoA inhibition after intracerebral hemorrhage in mice. Neurobiol Dis. 2012; 46(1): 204-14.

PubMed Abstract | Publisher Full Text | Free Full Text | F1000 Recommendation

90. F Fujii M, Duris K, Altay O, et al.: Inhibition of Rho kinase by hydroxyfasudil attenuates brain edema after subarachnoid hemorrhage in rats. Neurochem Int 2012; 60(3): 327-33

PubMed Abstract | Publisher Full Text | Free Full Text | F1000 Recommendation

91. Gajewski TF, Schreiber H, Fu YX: Innate and adaptive immune cells in the tumor microenvironment. Nat Immunol. 2013; 14(10): 1014-22. PubMed Abstract | Publisher Full Text | Free Full Text

92. F Medjkane S, Perez-Sanchez C, Gaggioli C, et al:: Myocardin-related transcription factors and $S R F$ are required for cytoskeletal dynamics and experimental metastasis. Nat Cell Biol. 2009; 11(3): 257-68. PubMed Abstract | Publisher Full Text | F1000 Recommendation

93. F Orgaz JL, Ladhani O, Hoek KS, et al.: 'Loss of pigment epithelium-derived factor enables migration, invasion and metastatic spread of human melanoma'. Oncogene. 2009; 28(47): 4147-61. PubMed Abstract | Publisher Full Text | Free Full Text | F1000 Recommendation

94. F Garcia M, Fernandez-Garcia NI, Rivas V, et al.: Inhibition of xenografted human melanoma growth and prevention of metastasis development by dual antiangiogenic/antitumor activities of pigment epithelium-derived factor. Cancer Res. 2004; 64(16): 5632-42.

PubMed Abstract | Publisher Full Text | F1000 Recommendation

95. F Ladhani O, Sánchez-Martinez C, Orgaz JL, et al.: Pigment epithelium-derived factor blocks tumor extravasation by suppressing amoeboid morphology and mesenchymal proteolysis. Neoplasia. 2011; 13(7): 633-42. PubMed Abstract | Publisher Full Text | Free Full Text | F1000 Recommendation

96. F Arozarena I, Sanchez-Laorden B, Packer L, et al.: Oncogenic BRAF induces melanoma cell invasion by downregulating the cGMP-specific phosphodiesterase PDE5A. Cancer Cell. 2011; 19(1): 45-57. PubMed Abstract | Publisher Full Text | F1000 Recommendation

97. F Calvo F, Sanz-Moreno V, Agudo-lbáñez L, et al:: RasGRF suppresses Cdc42-mediated tumour cell movement, cytoskeletal dynamics and transformation. Nat Cell Biol. 2011; 13(7): 819-26. PubMed Abstract | Publisher Full Text | F1000 Recommendation

98. $\mathrm{F}$ Padua $\mathrm{D}$, Zhang $\mathrm{XH}$, Wang $\mathrm{Q}$, et al:: TGFbeta primes breast tumors for lung metastasis seeding through angiopoietin-like 4. Cell. 2008; 133(1): 66-77. PubMed Abstract | Publisher Full Text | Free Full Text | F1000 Recommendation

99. Thiery JP: Epithelial-mesenchymal transitions in tumour progression. Nat Rev Cancer. 2002; 2(6): 442-54.

PubMed Abstract | Publisher Full Tex

100. F Redondo-Muñoz J, Ugarte-Berzal E, Terol MJ, et al.: Matrix metalloproteinase-9 promotes chronic lymphocytic leukemia b cell survival through its hemopexin domain. Cancer Cell. 2010; 17(2): 160-72.

PubMed Abstract | Publisher Full Text | F1000 Recommendation

101. Gould SE, Junttila MR, de Sauvage FJ: Translational value of mouse models in oncology drug development. Nat Med. 2015; 21(5): 431-9. PubMed Abstract | Publisher Full Text

102. Kircher MF, Gambhir SS, Grimm J: Noninvasive cell-tracking methods. Nat Rev Clin Oncol. 2011; 8(11): 677-88. PubMed Abstract | Publisher Full Tex 
103. Brader $P$, Serganova I, Blasberg RG: Noninvasive molecular imaging using reporter genes. J NuCl Med. 2013; 54(2): 167-72. PubMed Abstract | Publisher Full Text

104. Lawler K, Foran E, O'Sullivan G, et al:: Mobility and invasiveness of metastatic esophageal cancer are potentiated by shear stress in a ROCK- and Rasdependent manner. Am J Physiol Cell Physiol. 2006; 291(4): C668-77.

PubMed Abstract | Publisher Full Text
105. Reymond N, Riou P, Ridley AJ: Rho GTPases and cancer cell transendothelial migration. Methods Mol Biol. 2012; 827: 123-42. PubMed Abstract | Publisher Full Text

106. Parri M, Taddei ML, Bianchini F, et al.: EphA2 reexpression prompts invasion of melanoma cells shifting from mesenchymal to amoeboid-like motility style. Cancer Res. 2009; 69(5): 2072-81.

PubMed Abstract | Publisher Full Text 


\section{Open Peer Review}

\section{Current Peer Review Status:}

\section{Editorial Note on the Review Process}

Faculty Reviews are review articles written by the prestigious Members of Faculty Opinions. The articles are commissioned and peer reviewed before publication to ensure that the final, published version is comprehensive and accessible. The reviewers who approved the final version are listed with their names and affiliations.

\section{The reviewers who approved this article are:}

\section{Version 1}

\section{Michael Olson}

Cancer Research UK Beatson Institute, Glasgow, UK

Competing Interests: No competing interests were disclosed.

2. Martin A. Schwartz

Department of Internal Medicine, Cardiovascular Research Center, Yale University School of Medicine, New Haven, CT, USA

Competing Interests: No competing interests were disclosed.

The benefits of publishing with F1000Research:

- Your article is published within days, with no editorial bias

- You can publish traditional articles, null/negative results, case reports, data notes and more

- The peer review process is transparent and collaborative

- Your article is indexed in PubMed after passing peer review

- Dedicated customer support at every stage

For pre-submission enquiries, contact research@f1000.com 